\title{
Metallurgy and specialisation in Prepalatial Mesara, Crete
}

\author{
Thomas Tselios
}

Received: 21 May 2009/Accepted: 2 October 2009 / Published online: 6 November 2009

(C) Springer-Verlag 2009

\begin{abstract}
The purpose of this paper is to examine the technological knowledge and the technological level of copper metallurgy in the Mesara plain in Crete, during the Prepalatial period. In order to investigate this issue, objects from several (12) sites in the area were chosen for examination. In this way, the technological level of the area and each site could be safely ascertained. From the 55 objects that were examined, a very small sample was taken, which was the subject of metallographic and chemical analyses. By using these methods, the manufacturing processes for the production of each object, as well as the alloy that was used in each case, were identified. The combination of these two methods, along with typology of the objects and the number of objects produced at each site, provided safe conclusions as to the technological knowledge and the possible specialisation of metal production in each site and period. In the end, a lack of homogeneity in the Mesara plain was noticed as concerns the production of copper objects. Some sites seem to have a dominant position, with larger production and trading of metal artefacts, while other sites fail to provide any indication of metal production, and it is very possible that the metal objects were obtained from the neighbouring sites. Finally, the existence of specialised production is obvious in some sites in the Mesara plain, especially in the case of two groups of objects (triangular and long daggers), while the lack of organised and standardised production is obvious in the case of some other sites in the same area.
\end{abstract}

\footnotetext{
T. Tselios $(\bowtie)$

Department of History,

Archaeology and Cultural Resources Management,

University of Peloponnese,

24100 Kalamata, Greece

e-mail: thomastselios@yahoo.gr
}

Keywords Copper metallurgy · Alloys · Metallography · Mesara $\cdot$ Crete

\section{Introduction}

Craft specialisation constitutes a major factor in many theoretical models of social development and, in many cases, has formed the basis for analysis of the emergence of social complexity in the Aegean (Renfrew 1972; Earle and Brumfield 1987). In the case of Crete, there are many earlier studies of metal artefacts that focus mainly on typological classifications (e.g. Branigan 1968, 1974) and less based on aspects of production and distribution. On quantitative and typological criteria, we can assume that specific sites in the Mesara plain were production centres for these artefacts (Wilson and Day 1994, 242-244). However, in this way, it is not possible to understand the relationships between settlements in terms of production and distribution of artefacts, such as metal objects. Pottery studies have shown the complexity of pottery production and distribution in Crete (Wilson and Day 1994; Day et al. 1997; Whitelaw et al. 1997). However, for the study of metal artefacts, more extensive work is needed in order to obtain information about the models of production and distribution, as well as their changes in different chronological periods during the Prepalatial period.

This paper aims to contribute to this discussion by examining the way in which metal object manufacture was organised in Prepalatial Crete. The question that we will address here is whether Prepalatial metallurgy was a specialised industry or not. In the cases where specialised production can be detected, we will examine the nature of this specialisation. In general, craft specialisation has two main implications: the relatively limited number of persons 
involved in production and the manufacturing skills gained from the repetition of the procedures (Sbonias 2000).

Usually, two kinds of indications are related to craft specialisation (Schiffer 1991): (a) direct evidence related to the place where production takes place and (b) indirect indications as to the organisation of production, which can be detected in the final objects. Since direct evidence is almost completely absent during the Prepalatial period, information must, necessarily, be obtained from the final metal objects.

The selection of the objects and sites will be explained first, and then the discussion will focus on the methodology of the examination of manufacturing techniques and the information that can be extracted from such an examination. Finally, the issue of craft specialisation in Prepalatial Mesara will be discussed in full.

\section{Site and object selection}

The process of selecting suitable sites started together with my interest in Prepalatial Crete (Fig. 1). The main interest was to find some sites with a sufficient number of metal objects which would be representative of Prepalatial period. Since most finds from that period come from burial contexts, we necessarily had to study metal objects from burials.

Moreover, one of my main interests was the study of one specific area of the island, in order to try to identify production and distribution networks of metal objects at a local level. Consequently, Mesara (Fig. 2) was almost the only choice because of the many sites and objects from the Prepalatial period. So, to a degree, it was the existence of a large amount of objects in the Mesara that led us to the selection of these sites.

The aim of the object selection was the representation of the total amount of objects and object types found in the examined sites. Because this study is not mainly based on a typological approach, the intention was not to study all objects from all sites - since, for our approach, sampling from objects is necessary-but to take samples from as many types of objects as possible, since our intention is to obtain information about all the artefacts by studying only a part of them (Fletcher and Lock 1994; Drennan 1996; Orton 2000). Furthermore, the selected objects must not have been subjected to major conservation, in order that the

Fig. 1 Mesara area in central south Crete

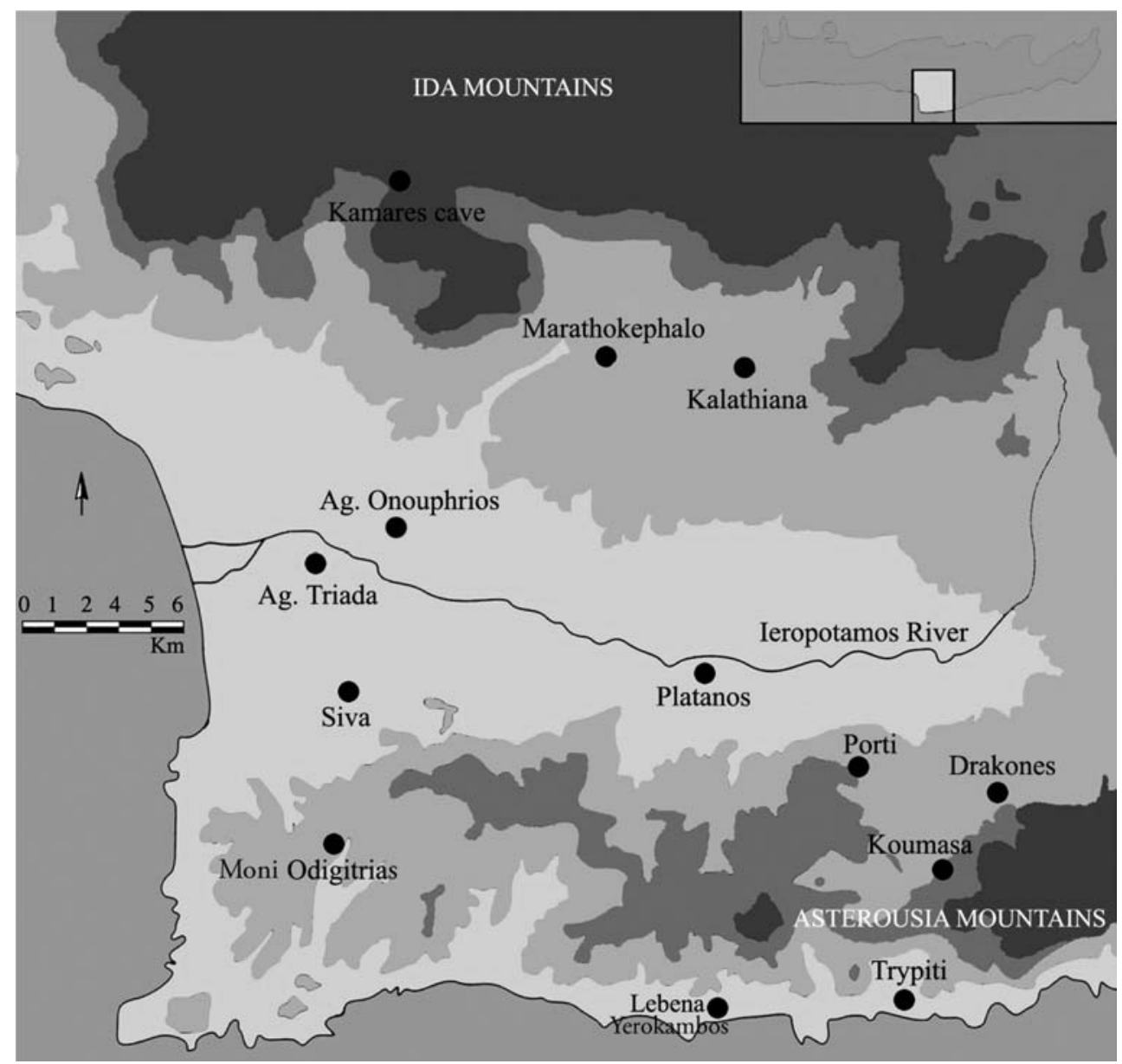




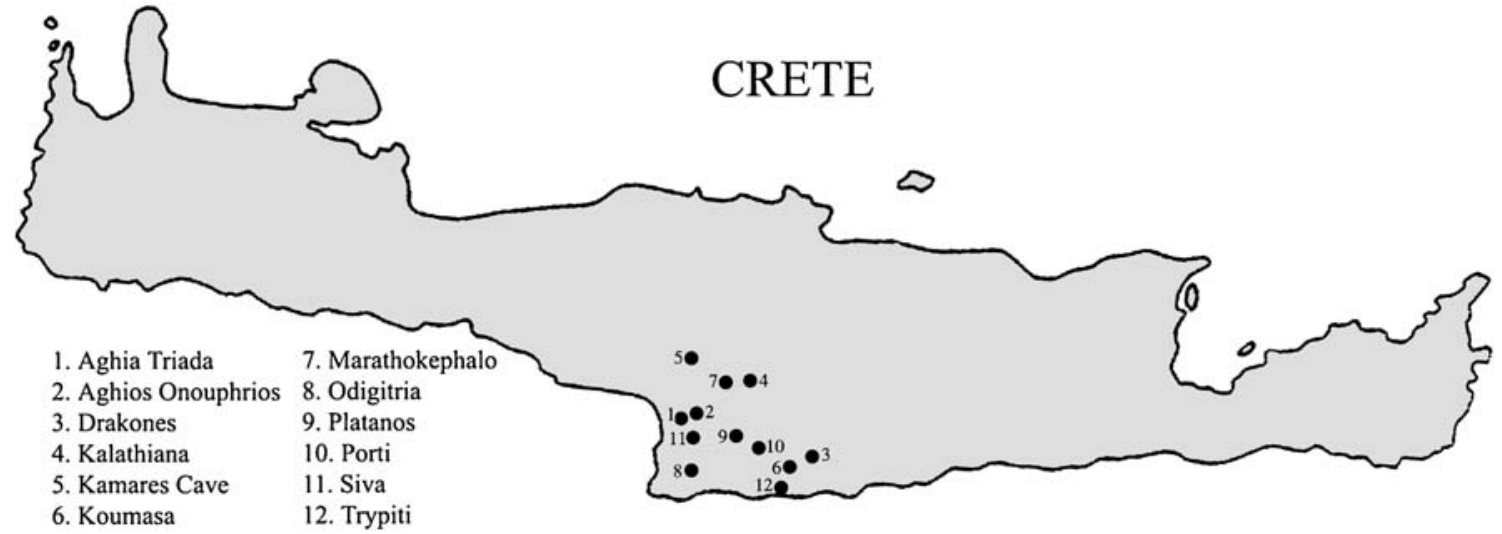

Fig. 2 Map of Crete with the examined sites

structural data which is under investigation should provide a reliable picture of ancient technology. Of course, we should take into account the fact that we could not select as many objects as we wished because a very small sample had to be cut from the object for the analyses (Tselios 2008).

The object selection took place at the store-room of the Herakleion Museum. The metal objects where stored in wooden boxes, usually one box per site, but in some case two or three boxes per site. The selection from each box and each site was random (Drennan 1996, 82-89; Orton $2000,14-39)$. The $30 \%$ of the total number of objects found in each box was selected randomly. Intentionally, the bibliography on the finds was not studied analytically, in order to avoid any bias in object selection.

Taking into consideration the area of interest and the available metal objects, the selected sites were (Fig. 1): Agia Triada (tholos tomb A), Agios Onouphrios (tholos tomb), Drakones (unknown context), Kalathiana (tholos tomb K), Kamares Cave, Koumasa (tholos tomb B and two triangular daggers from tholos tomb A or E), Marathokephalo (tholos tomb II), Moni Odigitrias (unknown context), Platanos
(8 objects from tholos tomb $A$ and 11 objects from unknown context), Porti (tholos tomb II), Siva (northern tholos tomb) and Trypiti (settlement) (for the complete catalogue of the objects, see Tselios 2008).

The 55 objects selected (Table 1) for study come from most Prepalatial sites in the Mesara plain and consist of 26 long daggers (Fig. 3a), 17 triangular daggers (Fig. 3b), five chisels (Fig. 3c), one double axe (Fig. 3d) and some other types of objects (Tselios 2008).

At this point, it is useful to note that copper objects cannot be dated with accuracy on the basis of typology, as is possible in the case of ceramics. For this reason, the best way to date such finds is through their association with other objects from the same context. However, almost all the objects examined here come from burial contexts, which makes dating through comparison very difficult, because these tombs were communal and used for many centuries, and the deposits in them were disturbed. Consequently, it is difficult to establish a burial correspondence between metal objects and other finds. In addition, the fact that most tombs were robbed not only in modern
Table 1 The selected metal objects

\begin{tabular}{|c|c|c|c|c|c|c|}
\hline Site & EMI-II & EMII & EMII-III & EMIII/MMIA & EM & ? \\
\hline Agia Trada & & 2 & 6 & & & \\
\hline Ag. Onouphrios & & & 1 & & & \\
\hline Drakones & & & & 1 & & \\
\hline Kalathiana & & & 2 & & & \\
\hline Koumasa & & 4 & 4 & 4 & & \\
\hline Kamares Cave & & & & & & 1 \\
\hline Marathokephalo & & 1 & 2 & 3 & & \\
\hline Moni Odigitrias & & & & & 1 & \\
\hline Platanos & 2 & & 4 & 12 & & 1 \\
\hline Porti & & & & 2 & & \\
\hline Siva & 1 & & & & & \\
\hline Trypiti & & & & & 1 & \\
\hline Total & 3 & 7 & 19 & 22 & 2 & 2 \\
\hline
\end{tabular}


Fig. 3 Types of examined objects. a Long Dagger from Platanos (tholos tomb A), b triangular dagger Koumasa (tholos tomb A or E), c chisel from Platanos (unknown context), d double axe from Platanos (outside tholos A)

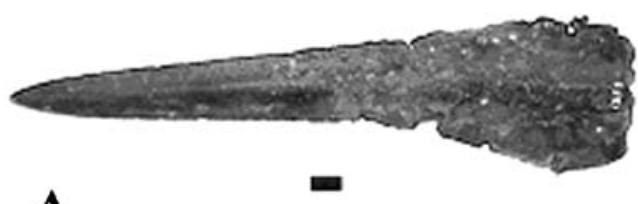

A.

B.

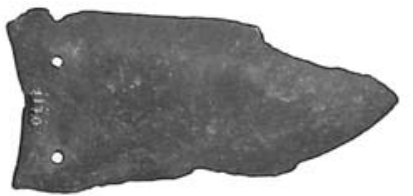

D.

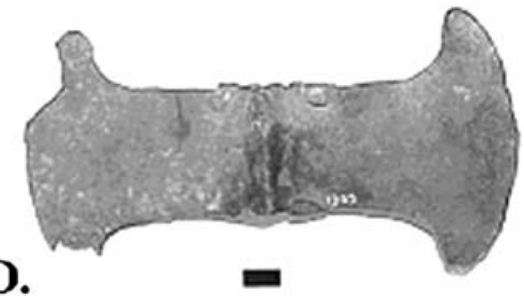

C. times but already in antiquity has resulted in disturbed depositions. Finally, inadequate excavation techniques used at the beginning of the twentieth century-when most of the tombs examined were excavated - do not allow developments over short periods of time to be seen. This is why colleagues who study metal objects very often use widerange chronological characterisations, which is a method that will be followed here as well.

\section{Methodology}

For the examination of the samples taken from the selected objects (Tselios 2006, 2008), a technique called metallographic analysis was used (Scott 1991; Tselios 2006, 2008). By this examination, we can understand the manufacturing procedures for each object from casting to the final object ready for consumption.

Different techniques were used in order to remove any imperfections from the object which may be created during casting and in order to make the final object tougher and the cutting edges sharper. Metallographic examination is based on the identification of characteristic shapes and forms that appear in metal grains, each of them representing a procedure that took place and changed the metal structure (Buchwald and Leisner 1990; Scott 1991). By this way, it is possible to identify procedures like hammering and annealing of the object (annealing is the heating of the metal up to $30 \%$ - if pure - or 50\% - if an alloy - of the appropriate melting point (Northover and Evely 1995, 93)), as well as the sequence of these procedures.

After the examination of all samples under the metallographic microscope, the following manufacturing techniques were identified: After the metallographic examination, all metal samples were subjected to chemical analyses using an analytical device called an electron probe microanalyser (Henderson 2000, 17-23), which revealed the chemical composition of the objects and, in general, the alloys used. On each sample surface, many area measurements (six to 12) were taken, in order to be sure that the analytical results of each sample were representative of the object (for a detailed description of the procedures followed, see Tselios 2008).

\section{The use of alloys by period}

During the EMI-II and EMII periods, the use of arsenical bronze was more widespread than that of tin bronze ${ }^{1}$ (Fig. 5). However, during the EMII-III period, there seems to have been an increase in the use of tin bronze compared to the EMII period. During the next period, EMIII/MMIA, it is obvious that the use of tin bronze increased, and in fact overtook the use of arsenic bronze. That is to say, it is noticeable that there is an upward trend in the appropriation of tin bronze earlier than some scholars believed (Branigan 1974; Mangou and Ioannou 1998). Finally, it is worth noting that, during the EMIII/MMIA period, a rise in the use of copper and/or arsenical copper seems to take place, whereas one would expect the disappearance of the use of pure copper.

Generally, during the EMII period, copper, arsenical bronzes and tin bronzes were used; however, the use of arsenical bronze was more widespread. In the case of the next two periods, EMII-III and EMIII/MMIA, all possible copper alloys were used. In general, in the Prepalatial period, arsenical bronze and tin bronze were used almost with the same frequency.

At this point, it is appropriate to comment on a supposed particularity of the Minoan metal industry, according to which, on Crete, there was a different tradition in metallurgy from the rest of the Aegean. This theory suggests that, in contrast with other areas, including the Cyclades (where tin alloy was used during the late periods of the Early Bronze Age and its use increased gradually

\footnotetext{
${ }^{1}$ For the chemical analyses, see Tselios (2008), Appendix 4.
} 
during the Middle Bronze Age), on Crete, the use of tin bronzes was delayed and appeared at the end of the Middle Bronze Age (Branigan 1974, 147-154; Mangou and Ioannou 1998). In the light of the chemical analyses of this study (Tselios 2008), this view is totally incorrect. Additionally, it must be noted that all previous analyses, on which the theory about Minoan individuality was based, were almost exclusively from objects from Agia Triada in the Mesara area (see Mangou and Ioannou 1998). However, Agia Triada is an exceptional case in comparison with the rest of the sites in the area. It is the only site where no tin bronze was used at all during the Prepalatial period. Since this theory was not based on statistically correct data, its conclusions were incorrect.

\section{The use of manufacturing techniques}

By examining the importance of manufacturing techniques, a general diffusion of techniques to all the sites examined without any substantial spatial distribution of each technique is observable (Table 2). The only fact that can be noticed is that techniques 2 (casting and then hammering) (Fig. 4b) and 5 (casting, annealing and hammering) (Fig. 4a) are the most common in all the samples examined.

Objects from Agia Triada, almost entirely, were manufactured using casting and then cold hammering. The similarities in metallographic structure are not accidental, and lead us to the assumption that these objects were manufactured either by the same metallurgist (in some cases) or at the same workshop. Indeed, the specific use of alloy used at Agia Triada (Tselios 2008), which is almost exclusively arsenical bronze, points in the same direction.

On the other hand, at the sites of Koumasa, Marathokephalo and Platanos, a diffusion of manufacturing techniques is noticeable. That is, no obvious homogeneity can be seen at those sites that will point to one workshop or metallurgist. The chemical examination of the alloys used leads to the same conclusion, since, in most cases, all available alloys were used. Manufacturing techniques become more complicated with the elapse of time (Figs. 5 and 6), which means that, during the earlier periods (EMIII), briefer manufacturing techniques were used than during later periods (EMII-MMIA). However, this does not mean that the technological level improved, since this comes about only by the right combination of manufacturing techniques with appropriate alloys.

At this point, we must underline as a basic principle that arsenical bronze up to $6 \%$ can be hammered without previous annealing, while for arsenical bronzes with arsenic more than $6 \%$ hammering without annealing is possible to cause cracks to the object (Papadimitriou 2001b). Tin bronzes, in general, are almost impossible to hammer without previous annealing; this would cause breaks in the object. When the percentage in tin exceeds $15 \%$, hammering is almost impossible even after annealing (Budd and Ottaway 1991).

\section{Metallurgy and specialisation in Prepalatial Mesara}

The manner of manufacturing of an object is very important for understanding the composition of ancient metal artefacts. Indeed, there must be a close relation between the chemical composition and the manufacturing techniques of an object (Papadimitriou 1991), since each component of an alloy gives to the final objects different properties. This correlation seems to be absent at the beginning of the Prepalatial period, but gradually, it develops and comes to its peak, according to Papadimitriou (2001a), during Geometric times. This observation leads to the conclusion that ancient metallurgists gradually realised the effects that composition had on the properties of casting and formation of copper alloys and, therefore, they chose, systematically and consciously, manufacturing techniques that were suitable for their raw materials.

The correlation of a specific technique (casting and hammering) with a specific alloy type (arsenical bronze) at Agia Triada reveals adequate knowledge of metallurgy and indicates a high technological level on the site. This provides
Table 2 Types of manufacturing techniques

\begin{tabular}{|c|c|c|c|c|c|}
\hline \multirow{2}{*}{$\frac{\text { Code }}{1}$} & \multicolumn{5}{|c|}{ Metalworking sequence } \\
\hline & Cast & & & & \\
\hline 2 & Cast $=>$ & Hammering & & & \\
\hline 3 & Cast $=>$ & Annealing & & & \\
\hline 4 & Cast $=>$ & Hammering $=>$ & Annealing & & \\
\hline 5 & Cast $=>$ & Annealing $=>$ & Hammering & & \\
\hline 6 & $($ Cast $)=>$ & Hammering $=>$ & Annealing $=>$ & Hammering & \\
\hline 7 & $($ Cast $)=>$ & Annealing $=>$ & Hammering $=>$ & Annealing & \\
\hline 8 & (Cast) $=>$ & Annealing $=>$ & Hammering $=>$ & Annealing $=>$ & Hammering \\
\hline
\end{tabular}


Fig. 4 Microphotographs (magnification $200 \times$ ) showing metal structures. a Long dagger from Kalathiana, (b) triangular dagger from Agia Triada

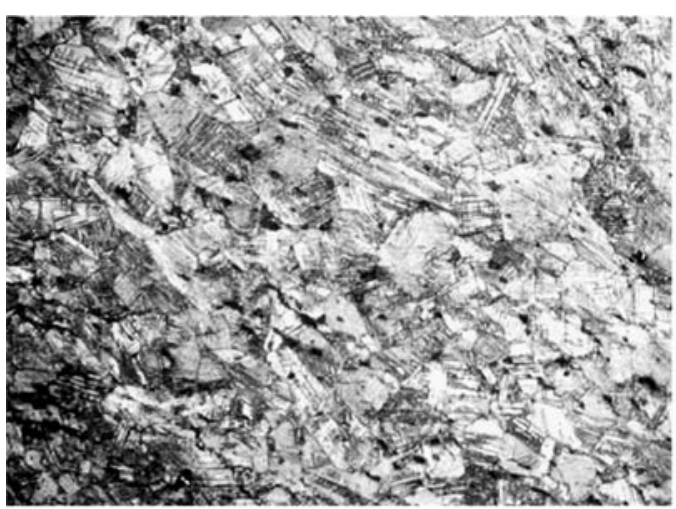

a. Casting, annealing and hammering

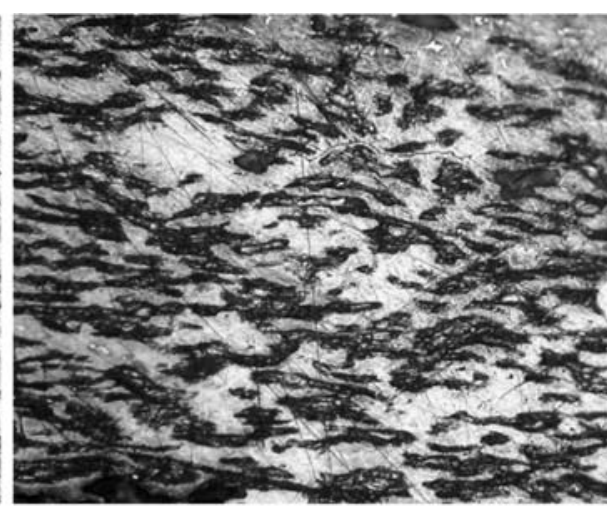

b. Casting and hammering one more indication along with specific standardised typological options that suggest a specific metallurgical workshop on the site, since only someone who works systematically in metal production can observe the properties of alloys and manufacturing techniques, in order to end up with the appropriate combination and standardised production.

At Koumasa, arsenic bronze and tin bronze were used almost in the same proportion, for the same types of objects and for the same chronological periods (EMII-III and EMIII/MMIA). This indicates that the properties of tin in copper were realised, and that is why annealing before hammering was practised in manufacturing objects. However, in the case of arsenic bronzes, there is no obvious standardisation in manufacturing techniques such as is observable at Agia Triada. Therefore, we can suppose that, even if the level of manufacturing from tin bronzes was high, craft specialisation was not as high as that at Agia Triada for arsenical bronzes.

In the case of the rest of the sites examined, no specific alloy type or metalworking techniques were preferred. Typologically, at Platanos and Marathokephalo, metalworkers seem to have manufactured their own, distinct types of objects, but it is not possible to attribute these to one specific workshop at each site. Probably, we have to do with occasional metalworkers who manufactured objects from the available raw materials, without specialisation and standardisation in metal production. There are, however, some groups of objects (on the basis only of typological criteria-e.g. long daggers Braningan's type V (Branigan 1968)) from these sites which can possibly have been made by the same metalworker (Tselios 2008). This does not indicate the existence of a specialised workshop, but probably the amateurish manufacture of objects typologically characteristic of the site by metalworkers who knew the processes more or less, but did not have the profound knowledge of alloys that repetition and mass production provides. It is noticeable that, because of this lack of specialisation and experience, in the case of long daggers, more lengthy manufacturing techniques were used than for triangular daggers. However, it is the type of the alloy-as mentioned above - and not the length of the artefact that matters in manufacturing processes. This combination of manufacturing techniques and alloys began to be applied when tin was used systematically, and probably, it was noticed that, without previous annealing, hammering can cause cracks or even breaking of the object.

Fig. 5 Alloy type by period
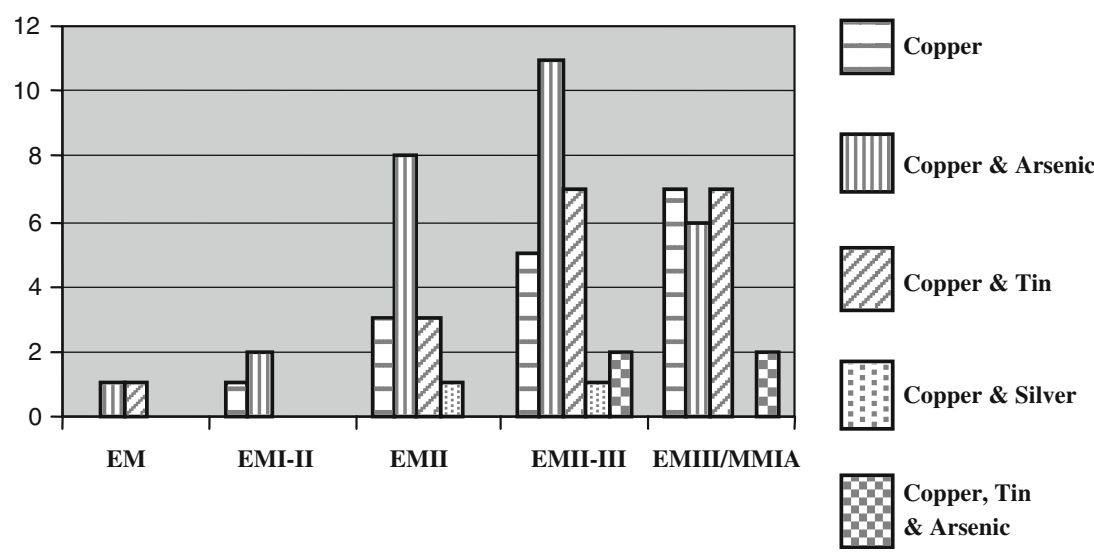


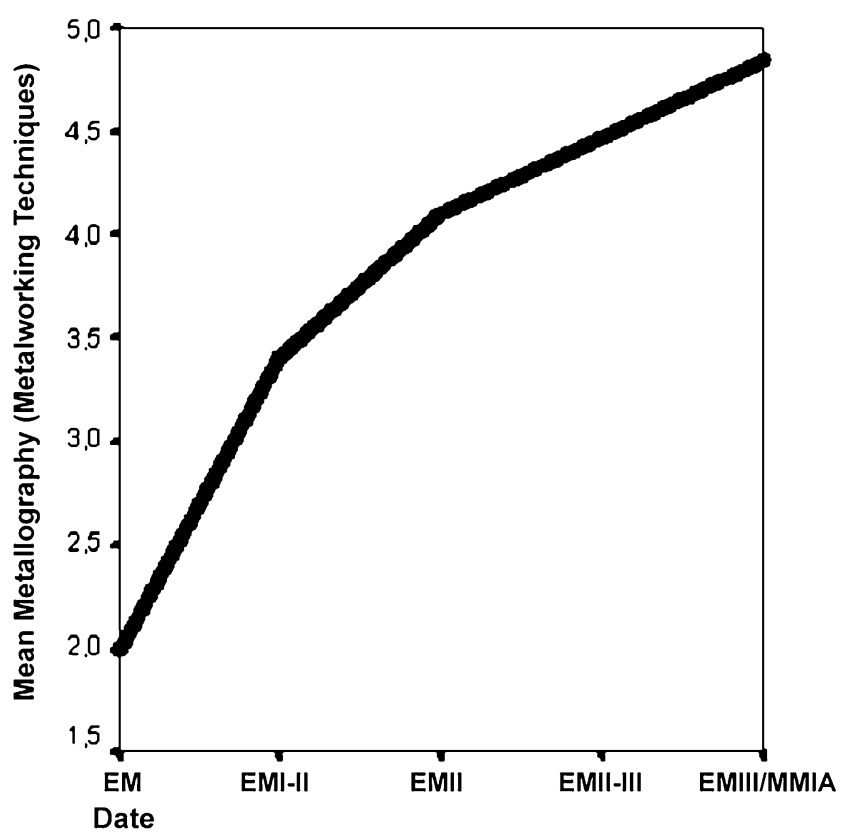

Fig. 6 Manufacturing techniques by period

\section{Technological options and sites examined}

As was explained above, the technological level at Agia Triada is quite high, but the most important fact is that we observe craft specialisation at the site, which is not noticeable to that degree at any other site in the area. However, the technological level at Agia Triada is not the highest that it could be. For instance, if arsenical bronzes had been used in combination with the appropriate manufacturing techniques (as at Agia Triada) and tin bronzes with the appropriate manufacturing processes (Tselios 2008) for specific and characteristic types of objects, then the technological level would have been the highest for the area and for the period. Nevertheless, something like that would presuppose, apart from knowledge of the properties of metals, the availability of arsenic, as well as of tin.

Having analysed the technological level of the larger sites in the Mesara area, we can conclude the following: In the area of Mesara, no homogeneity in the production of metal objects is observable. The site of Agia Triada clearly shows a high technological level and craft specialisation in metal production. Metallurgists at Koumasa adapted their production to the available copper-tin alloy (tin bronze), which indicates quite a high technological level. At Platanos, despite the huge number of metal objects that were found, homogeneity in production is not observed. Even if it is possible for some groups of objects to emerge, which may indicate specific workshops, mainly in the case of long daggers (Branigan 1968, long daggers type $\mathrm{V})$, this grouping is based only on typology. The only fact noticeable at the site is that, for shorter daggers, briefer metalworking techniques and, for longer daggers, more lengthy manufacturing techniques were used, which indicates the unspecialised nature of the production, since, as we mentioned above, the important factor is the correct combination of alloy and manufacturing technique. Similar indications have been obtained from Marathokephalo as well.

At this point, someone may argue that such differentiation in manufacturing processes may have been the result of differentiation in use of the objects. However, something like that does not seem to be valid here because both types of objects (triangular and long daggers) seem to have the same traces of use. Therefore, we cannot assume that they were used for different purposes.

Consequently, we can say that each site in the Mesara area follows its own path in metalworking production. Some of them have a high technological level, while others either have totally occasional and amateurish production or the properties of alloys cannot have been understood. Very often, most of the technological options are determined by the raw materials and exchanges available. Therefore, there is frequently no homogeneity at area level or even at the same site. Technological options are the same more or less for the whole Mesara area, but the important thing which frequently determines these choices is the availability of metals and trade.

\section{Copper objects and site hierarchy}

The cemeteries of Agia Triada, Platanos and Koumasa in the Mesara plain appear to have a higher proportion of imported and specialised objects than the rest of the cemeteries in the area. The distribution of copper objects indicates that specific groups among the communities of Agia Triada, Platanos and Koumasa in Mesara had privileged access to status objects. Of course, this existence of a large number of characteristic types of objects at those sites indicates the dominance of these sites in metal production. Objects that, in typological terms, seem to have been produced at these sites were found at other, smaller, sites, like Lebena, Siva and Marathokephalo (Watrous et al. 2004, 256-258).

Most Prepalatial daggers were manufactured at the centres of Mesara, such as Agia Triada, Koumasa and Platanos. Most of these sites had their own distinct manufacturing techniques (Tselios 2008) and their own characteristic types of daggers (Branigan 1968, 56, 1974, 127-128). However, some of these daggers were found at peripheral sites around these MMIA centres - a distribution remarkably different from the EMII concentration model. Triangular daggers characteristic of Agia Triada were found 
at Siva, Odigitria and Marathokephalo, while long daggers characteristic of Platanos and Koumasa were found at Lebena (Watrous et al. 2004, 256-258).

Craft specialisation and exchanges followed the same path during the Prepalatial period. During the EMI-II period, in the Mesara plain, metalworkers and potters were manufacturing specialised products for groups of people at the site, the 'elites', and for exchanges. In the time until the MMIA period, the number and types of specialised objects, such as daggers and seals, increased dramatically. Social differentiation became more intense. By the end of Prepalatial period, features of social stratification appeared in the communities. Status objects and tombs multiplied during the MMIA period. During the Prepalatial period, social stratification made a leap, and as Watrous et al. (2004, 249-251) suggest, three or possibly four social ranks can be observed in material culture by the end of this period.

\section{Conclusions}

Technological developments and changes do not necessarily indicate craft specialisation in the case of the sites examined. In order for it to be considered that there is craft specialisation in the production of metal objects at a site, three factors must be combined: (a) alloys, with (b) the manufacturing processes appropriate to them, and (c) the types of objects characteristic of the site. Having this in mind, we can say that, at Agia Triada and Koumasa, specialised production is present.

At Agia Triada, arsenical bronze and standard manufacturing techniques were used exclusively for the production of characteristic types of objects (triangular daggers). However, this production was somewhat conservative, since no tin bronze was used as it was at all other sites in the Mesara plain. At Koumasa, while arsenical and tin bronzes were used almost equally for the same types of objects, it seems that only the properties of tin in copper were observed, and for that reason, the appropriate manufacturing techniques was used. Consequently, craft specialisation at Koumasa was not the highest possible. At Platanos, despite the huge number of metal objects found there, there are no obvious indications of specialisation. Even if groups of objects sharing similar typological characteristics have been identified, and therefore, these could have been produced at the same workshop, nevertheless, the manufacturing techniques and alloys used do not lead us to the same assumption.

The production of metal daggers, or at least of daggers to be 'consumed', seems to have been concentrated mainly in centrally sited settlements. This seems natural, since it is in larger settlements that social stratification first arises, and metal objects which are manufactured from an imported material seem to be status objects (Helms 1981; Broodbank 1993). It is worth noting that, during the EMII period, status products were limited to the larger settlement centres, and the regional economic network was not involved in the distribution of such status objects.

During the MMIA period, it is noticeable that the production of metal objects and objects manufactured from other materials increased in comparison with the EM period. The rise in the production of artefacts such as copper-based objects, ivory seals and stone vases indicates a steep rise in living standards, as well as a demographic rise. Status objects are not limited any more to the settlement centres (as in the EMII period), which could indicate a wider distribution of wealth and a more complex economic network.

Acknowledgements I would like to thank the General Secretariat for Research and Technology (Ministry of Development) for financing my study, as part of a programme called PENED. Moreover, I would like to thank the University College of London, because a part of the analytical work for this study was done at the Wolfson Archaeological Science Laboratories at the University College of London, Institute of Archaeology, and it was funded by the European Union under a Marie Curie Host Fellowship for Early Stage Researchers Training.

\section{References}

Branigan K (1968) Copper and Bronze Working in Early Bronze Age Crete. Studies in Mediterranean Archaeology 19. Carl Bloms Boktryckeri, Lund

Branigan K (1974) Aegean Metalwork of the Early and Middle Bronze Age. Oxford University Press, Oxford

Broodbank C (1993) Ulysses without sails. Trade, distance, knowledge and power in the Early Cyclades. World Archaeol 24:315-331

Buchwald VF, Leisner P (1990) A metallurgical study of 12 prehistoric bronze objects from Denmark. J Dan Archaeol 9:64-102

Budd P, Ottaway B (1991) The properties of arsenical copper alloys: implications for the development of eneolithic metallurgy. In: Budd P, Chapman B, Jackson C, Janaway R and Ottaway B (eds.) Archaeological Sciences 1989. Oxbow Books, Oxford, pp 132-142

Day P, Wilson D, Kiriatzi E (1997) Reassessing specialization in Prepalatial Cretan ceramic production. In: Laffineur R, Betancourt $\mathrm{P}$ (eds) TEXNH. Craftsmen, Craftswoman and Craftsmanship in the Aegean Bronze Age. Aegaeum 16. Université de Liège, Liège, pp 275-289

Drennan RD (1996) Statistics for archaeologists: a commonsense approach. Plenum, New York

Earle TK, Brumfield EM (1987) Specialization, exchange and complex societies: an introduction. In: Earle TK, Brumfield EM (eds) Specialization, exchange and complex societies. Cambridge University Press, Cambridge, pp 1-9

Fletcher M, Lock GR (1994) Digging Numbers. Elementary Statistics for Archaeologists. Oxford University Committee for Archaeology, Oxford

Helms M (1981) Precious metals and politics: style and ideology in the Intermediate Area and Peru. J Lat Am Lore 7:215-238

Henderson J (2000) The Science and Archaeology of Materials. Routledge, London 
Mangou H, Ioannou PV (1998) On the chemical composition of prehistoric Greek copper-based artifacts from Crete. Annu Br Sch Athens 93:91-102

Northover P, Evely D (1995) Towards an appreciation of Minoan metallurgical techniques: Information provided by copper alloy tools from the Ashmolean Museum. Oxford. Annu Br Sch Athens 90:83-105

Orton CR (2000) Sampling in Archaeology. Cambridge University Press, Cambridge

Papadimitriou G (1991) Copper and bronze metallurgy in Ancient Greece. In: Pernicka E, Wagner G (eds) Proceedings of the International Symposium on Archaeometry. Birkhauser, Basel, pp $117-126$

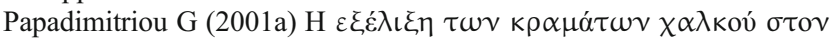

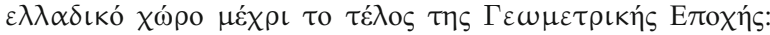

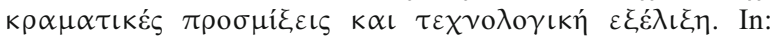
Bassiakos Y, Aloupi E, Fakorelis G (eds) Archaeometrical Studies for the Hellenic Prehistory and Antiquity. Hellenic Society of Archaeometry, Institute for the Messenian Archaeological Studies, Athens, pp 587-608

Papadimitriou G (2001b) Simulation study of ancient bronzes: their mechanical and metalworking properties. In: Bassiakos Y, Aloupi E, Fakorelis G (eds) Archaeometrical Studies for the Hellenic Prehistory and Antiquity. Hellenic Society of Archaeometry, Institute for the Messenian Archaeological Studies, Athens, pp $713-733$

Renfrew C (1972) The Emergence of Civilisation: The Cyclades and the Aegean in the Third Millennium BC. Meuthen, London
Sbonias K (2000) Specialization in the Early Minoan seal manufacture: Craftsmen, settlements and the organization of production. In: Pini I (ed) Corpus Der Minoischen Und Mykenischen Siegel. Minoisch-Mykenische Glyptik Stil, Ikonographie, Function. Gebr. Mann Verlag, Berlin, pp 277-293

Schiffer MB (ed) (1991) Archaeological Method and Theory 3. The University of Arizona Press, Tuscon

Scott DA (1991) Metallography and Microstructure of Ancient and Historic Metals. The Getty Conservation Institute, The J.Paul Getty Museum, Singapore

Tselios T (2006) A new look at Minoan metalworking techniques. In: Day J, Greenlaw C, Hall H, Kelly A, Matassa L, McAleese K, Saunders E, Stritch D (eds) SOMA 2004. Symposium on Mediterranean Archaeology. BAR International Series 1514, Archaeopress, Oxford, pp 193-197

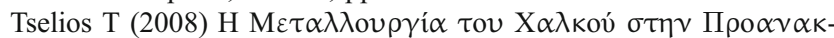

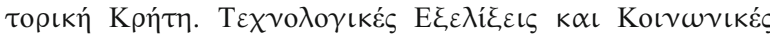
'O $\psi \varepsilon\llcorner\varsigma$. Kardamitsa, Athens

Watrous LV, Hadzi-Vallianou D, Blitzer H (2004) The Plain of Phaistos. Cycles of Social Complexity in the Mesara Region of Crete. Cotsen Institute of Archaeology, University of California, Los Angeles

Whitelaw T, Day PM, Kiriatzi E, Kilikoglou V, Wilson DE (1997) Ceramic traditions at EM IIB Myrtos, Fournou Korifi. In: Laffineur R, Betancourt P (eds) TEXNH: Craftsmen, Craftswomen and Craftsmanship in the Aegean Bronze Age. Aegaeum 16. Université de Liège, Liège, pp 265-274

Wilson D, Day P (1994) Ceramic regionalism in Prepalatial Crete: the Mesara imports at EMI to EMIIA Knossos. Annu Br Sch Athens 89:1-87 